\title{
STRATIGRAPHICAL SECTION THROUGH LOWER CAMBRIAN AT SÖDERFJÄRDEN, VAASA, WESTERN FINLAND
}

\author{
JYRKI J. LEHTOVAARA
}

\begin{abstract}
LEHTOVAARA, JYRKI J. 1982: Stratigraphical section through Lower Cambrian at Söderfjärden, Vaasa, western Finland. Bull. Geol. Soc. Finland 54, 1-2, 35-43.
\end{abstract}

The Lower Cambrian sedimentary rocks form a doughnut-shaped deposit on the bottom of the Söderfjärden depression. The sedimentary pile was first established and has now been penetrated by drilling. The remaining thickness of sedimentary rocks at the drilling site is $244 \mathrm{~m}$ under $74 \mathrm{~m}$ of glacial overburden.

Sediments in the lower half of the sequence are clayey and continue in the upper half mixed with sandy and silty beds. Thin phosphoritic conglomerates intercalate with any other rocks. Syndepositionary sedimentary structures and penecontemporaneous soft-state deformations are well preserved in these completely unmetamorphosed rocks. Indications of rapid basin filling are met with throughout the sequence.

A volcanic origin of Söderfjärden basin, Lower Cambrian in age, is claimed to have implications with coeval alkaline magmatism in the Fennoscandian Shield.

Jyrki J. Lehtovaara, Institute of Geology and Mineralogy, University of Turku, SF-20500 Turku 50, Finland.

\section{Introduction}

The flat, rounded field of Söderfjärden is situated some $10 \mathrm{~km}$ south of the centre of Vaasa and is surrounded by low rocky hills. During the last decade geophysics and drilling revealed it to be an exceptional, sedimentary rock -filled depression of considerable depth in the Precambrian terrain (Laurén et al. 1978). The sedimentary rocks of the drilled top layers were found by Tynni (Laurén et al. 1978) to be Lower Cambrian in age overlain by a Pleistocene overburden of $70-80 \mathrm{~m}$ of till and silty and sandy material. The Lower Cambrian sequence (Fig. 1) was not, however, fully intersected until 1979. Only summaries of this operation have been written (Lehtovaara 1980, 1982).

Laurén and others (1978) concluded that this sizeable depression, about $5 \mathrm{~km}$ in diameter, originated in an explosion. The occurrence of the explosion was established by the discovery of tuffaceous breccia material in holes drilled into the bottom in the middle of Söderfjärden. The depression therefore had to be a crater, and one that was more probably of volcanic than of meteorite-impact origin. A sedimentation basin, its maximum depth exceeding $300 \mathrm{~m}$ (Lehtovaara 1982), had thus suddenly come into existence. Tal- 


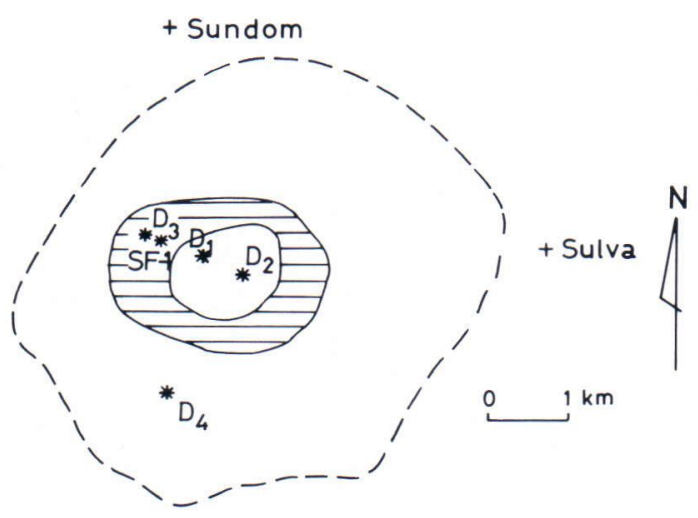

Fig. 1. Lower Cambrian sedimentary rocks form a doughnut-shaped (hatched) remnant on the bottom of the Söderfjärden sediment plain the approximate contours of which are marked with a dashed line. The drilling sites are marked with asterisks, $\mathrm{D}_{1}-\mathrm{D}_{4}$ drillings reported in Lauren and others (1978) and SF-1 the drilling at hand.

vitie and others (1975) had earlier interpreted Söderfjärden as a downfaulted block.

The present paper contains a systematic description of the core of the intersection drilled in 1979 (Table 1), together with other observations and measurements. A brief comparison is given with other data. The local origin and geological history are discussed in a general sense.

\section{Description}

\section{Drilling results}

On grounds of seismic logging, drill hole SF-1 of 1979 apparently represents the maximum thickness of the sedimentary rock succession (cf. also Laurén et al. 1978, Fig. 6). At the earlier drilling site, where the sedimentary rocks were first discovered, the thickness of loose overburden was $72 \mathrm{~m}$ (op. cit., p. 11). At the new site, $120 \mathrm{~m}$ east of the earlier one $\left(D_{3}\right.$, Fig. 1), the Cambrian layers were reached at $74.35 \mathrm{~m}$ (Table 1). The sedimentary sequence continued to $318.08 \mathrm{~m}$, from where drilling was extended to a depth of $347.25 \mathrm{~m}$ into the basement of the sedimentary rocks.

Table 1. The drill-indicated Lower Cambrian sedimentary sequence at Söderfjärden.

\begin{tabular}{ll}
\hline depth & rock type \\
\hline $00.00-74.35$ & $\begin{array}{l}\text { overburden: silt and sand above a basal till. } \\
\text { sandstone: pale grey; fine-grained and brittle; with clayey laminations and layers; one } \\
\text { clear-cut contact against shale; a few phosphoritic pebbles } 1-3 \text { mm in diameter. }\end{array}$ \\
$74.35-76.45-78.40$ & shale: greyish green; mixed with silt, base sandy with a sharp contact. \\
$78.40-78.53$ & $\begin{array}{l}\text { greywacke: greenish; larger grains and sedimentary rock fragments in clayey silty matrix; } \\
\text { many quartz grains shock-like lamelled and broken, some kinked biotite flakes; a little } \\
\text { glauconite. }\end{array}$ \\
$78.53-86.40$ & $\begin{array}{l}\text { shale: greyish green; with sandstone and greywacke-like intercalations; bedding varies } \\
\text { strongly, also minor folds. }\end{array}$ \\
$86.40-92.65$ & $\begin{array}{l}\text { sandstone: pale brownish (secondary) with reddish laminae; lower contact clear-cut, } \\
\text { microfaults; some quartz overgrowth, brownish pigment, and calcite. }\end{array}$ \\
$92.65-92.98$ & $\begin{array}{l}\text { greywacke: greenish; minerals and structures as in the greywacke above. } \\
\text { sandstone: pale grey; frequently intercalated with shale, its topmost bed graded; some } \\
\text { angular shale fragments and larger quartz crystals having a few shock-like lamellae. }\end{array}$ \\
$92.98-97.30$ & $\begin{array}{l}\text { sandstone: greyish white; impure with several clayey and silty intercalations; grading in } \\
\text { thicker beds; slumping structures visible, some microfaults. } \\
\text { siltstone: greyish-greenish; lower contact abrupt, upper contact gradual; slumping } \\
\text { frequent, pieces up to 10 cm; matrix mixed, cemented with some calcite and glauconite. }\end{array}$
\end{tabular}


127.63-131.50 shale: greyish green; mildly varved; sandy layers; minor folds in shale, strongly slumped, coarsening at the base; some pyrite concretions.

131.50-140.35 shale: greyish green; silty interlayers and a few phosphoritic pebbles; relatively undisturbed; clearly but varyingly glauconitic.

140.35-140.43 conglomerate: brownish phosphoritic pebbles, $1-2 \mathrm{~cm}$, of differing shades; clayey matrix. 140.43-142.30 shale: greyish green; slightly glauconitic; deformed.

142.30-142.45 conglomerate: brownish phosphoritic pebbles, up to $3 \mathrm{~cm}$; greenish matrix of shale and sandstone; cementing pyrite and calcite; grain size strongly varying.

142.45-146.90 siltstone: greyish; glauconitic stripes and a few pyrite concretions; strongly slumped and microfaulted but not the clayey top portion.

146.90-148.70 sandstone: greyish white; bright green at stripes where authigenic glauconite as the sole cement; a few phosphoritic pebbles; grain size coarsening downwards, strongly laminated with shale and slumped.

148.70-166.30 shale: greyish green; with silty and sandy interlayers; some slumping.

166.30-192.80 sandstone: greyish white and brittle; frequently laminated with shale especially at the base; white calcite spots $(1-2 \mathrm{~cm})$ and stripes as cement, some pyrite concretions conformable with bedding; microfaults well visible and slumping in shale; a few tourmaline and glauconite grains.

192.80-192.95 conglomerate: pale brown clasts of strongly varying sizes, in a chaotic matrix with many grain sizes; bent shale laminae; some calcite and pyrite cement.

192.95-197.70 sandstone: pale greyish; thin wavy clay laminae, grain size fining topwards; spotty with calcite.

197.70-208.30 sandstone: a larger unit clearly graded, fining into shale at top; scattered brown phosphoritie pebbles, also angular fragments; phosphorite much replaced by calcite; zircon frequent as thin stripes, glauconite also as cement together with quartz overgrowth.

208.30-209.95 shale: greyish green; strongly laminated with sandy and silty layers; small-scale slumping.

209.95-215.30 sandstone: pale greenish white; less sorted than usual; some overgrowth of quartz and calcite spots.

215.30-262.00 shale: greyish green and soft, breaks like a modern clay on drying; commonly varved with silt, varve thickness $2-5 \mathrm{~cm}$, varves often destroyed by small-scale slumping; only sandstone layer at 233.00-233.40; solitary phosphoritic pebbles and pyrite concretions; tourmaline and clastic glauconite in coarser layers together with zircon and epidote; chlorite and white mica in clayey material.

262.00-262.08 conglomerate: pale brown; contacts againt shale abrupt; flat pebbles up to $2 \mathrm{~cm}$, made up of different grain fractions cemented with brown varyingly phosphoritic material; calcareous cement between pebbles, also replacing phosphorite; pyrite also cementing.

262.08-313.25 shale: greyish green; of much the same qualities as above; graded, coarsening at the very bottom and a few coarser laminations.

313.25-314.04 siltstone: greyish; a mixture with sandstone fragments, in places conglomeratic with phosphoritic pebbles; calcareous and glauconitic; slumping advanced.

314.04-314.28 sandstone: white with green undisturbed laminae; lower contact disturbed; calcareous cement, detrital glauconite enriched at the green laminae.

314.28-314.48 siltstone: greenish; clayey matrix with larger feldspar and quartz grains, not quite a greywacke.

314.48-316.07 shale: dark green and soft; with few thin layers of hard sandstone, greywacke, and conglomerate.

316.07-316.94 shale: dark green; an almost equal amount of thin sandy layers hardened by a complete overgrowth of quartz, orthoquartzitic in composition, with zircon, sphene, pyrite, and tourmaline.

316.94-317.55 shale: dark green and soft; some sandy intercalations.

317.55-318.08 greywacke: greenish; a mixture of different size fractions; clayey-silty matrix and fewer rusty sand flasers; structure somewhat chaotic and contact with the basement clear-cut; authigenic tourmaline.

318.08-347.25 basement: migmatite of mica gneiss and granodiorite; little altered, mostly at thin stripes and top $15 \mathrm{~cm}$. 
Basement rocks

The Cambrian rocks rest directly on the local bedrock, a heterogeneous migmatitic granodiorite. No Jotnian or even Vendian sedimentary rocks lie between the Cambrian and its basement. The whole sedimentary rock sequence of $243.73 \mathrm{~m}$ has been dated Lower Cambrian (Tynni, pers. com. and this issue).

Like the granodiorite in the earlier drillings (holes 1, 2 and 4 in Laurén et al. 1978), here, too, the basement of the sedimentary cover seems to be altered. The average degree of alteration decreases downwards. In the earlier drillings, a tuffaceous breccia with fragments varying in size but chemically of the same composition as the country rock was met with over a wide area. Here, at $1.5 \mathrm{~km}$ from the centre of the crater, only a few thin diffuse stripes of more broken rock occur; there are no clear-cut bands or layers. Some small carbonate veins also cut the country rock.

The topmost $15 \mathrm{~cm}$ of the granodiorite is conspicuously rusty. Microscopically this rock consists of a "groundmass" of finer grains together with oriented larger biotite, partially "burned" but not kinked, and of still larger separate grains of rather fresh quartz and feldspars.

Only a few comments concerning the altered granodiorite proper are appropriate, as it has been described in some detail by Laurén and others (1978, pp. 18-19). Undisputed shock lamellae in quartz have not been seen at this distance from the crater centre. Rather, the tectosilicates, and especially plagioclase, are in many places broken into a fine mosaic of minute pieces that include some glass, just as was observed in earlier drillings. The broken material is sometimes associated with that of the neighbouring grains and forms microscopic stripes or veins of tuffaceous breccia. Downwards from the topmost "crust" of the granodiorite, biotite and chlorite become kinked once more.

\section{Sedimentary cover}

The sequence of the sedimentary rock strata in the core of the new drill intersection $\mathrm{SF}-1$ (Fig. 1) is given in rough detail in Table 1. This description is based primarily on macroscopic observations and augmented by data on thin sections. Excluding some still thinner conglomerate beds and other singular rock types, the thinnest layers discerned here are of the order of $50 \mathrm{~cm}$ in thickness. The true sequence is, however, much more complicated, especially if the lamination is also considered. The diagram in Fig. 2 is a somewhat more detailed presentation of the data in Table 1, in which the thinnest beds in the figure could not be described.

The only new rock type encountered in the drilling was a greywacke. The other rock types and common features of these rocks have been described by Laurén and others (1978); hence the present author has limited his account of these points to additions, alterations, and comparisons.

The macroscopic classification of the sedimentary rocks now revealed appeared, as a whole, to be best aligned with the Wentworthian division (Pettijohn 1975) into sedimentary rock types based on logarithmic grain sizes. This differs somewhat from the earlier practice of the present author (cf. Laurén et al. 1978, pp. 23, 27). The conglomerate is a rock type with well-rounded flat brown pebbles and a rather marked size gap towards the sandstones (cf. Fig. 4 by Tynni, this issue). The latter rocks mainly consist of the finer grain fractions and grade into siltstones (classed in the $1 / 16-1 / 256 \mathrm{~mm}$ size). The siltstones can be roughly identified by their commonly greyish colour, whereas the sandstones are whiter. The greenish shales, or rather claystones, were soft after drilling and 


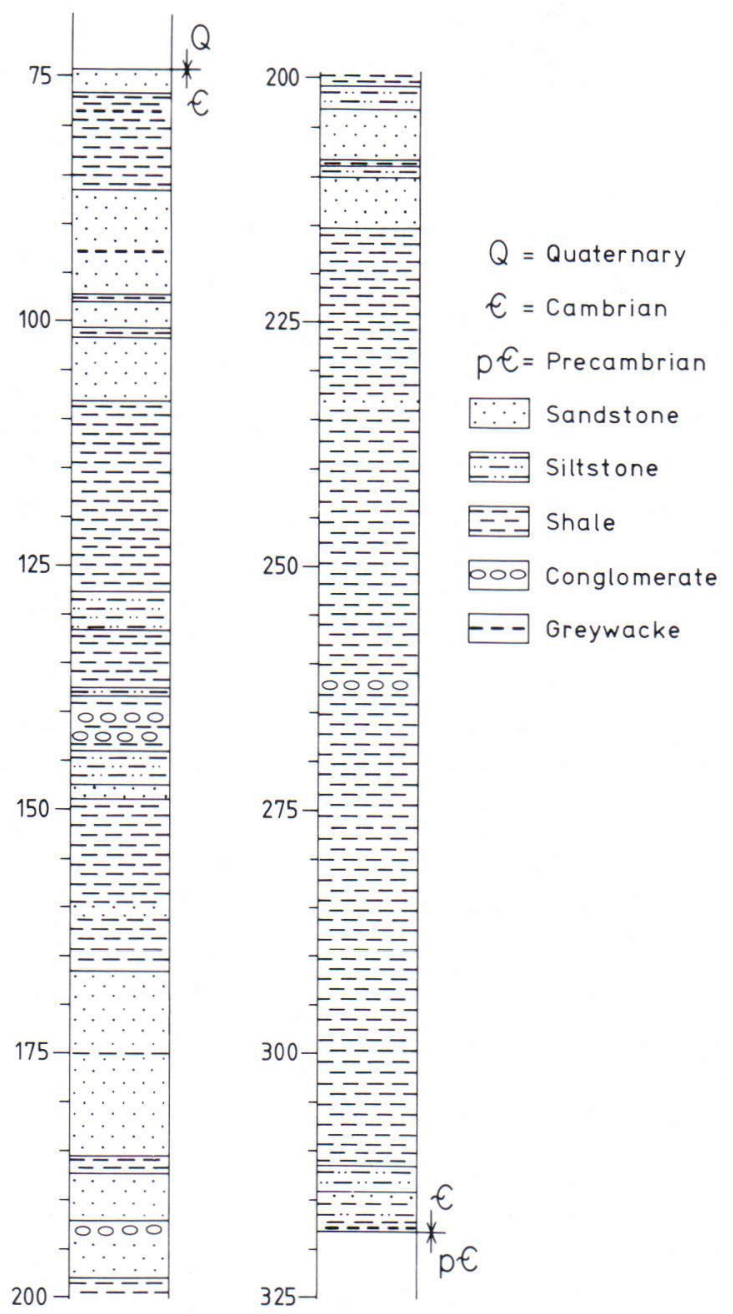

Fig. 2. A simplified diagrammatic presentation of the succession of sedimentary rock strata at the SF-1 drilling site. All bedding planes are inclined, the angle of dip varying rapidly. Bed contacts are shown with a continuous line. Where the beds are too thin (less than $1 / 2 \mathrm{~m}$ ) but important, they are indicated only with the rock type markings.

even the relatively coarse Wentworthian grain size limit has obviously often been exceeded. Thin layers of a very unsorted mixture containing most of the size fractions were denoted greywacke. This rock type normally contains unrounded fragments of other sedimentary rocks as well.
Mineralogically this intersection of the whole sedimentary pile confirmed some characteristic features. Authigenic tourmaline occurs throughout the sequence (see Table 1). The sequence is also glauconitic particularly around depths of $130-150 \mathrm{~m}$ where the glauconite occurs as cementing material; elsewhere it is met with as separate grains. The lowermost sandstone layers are cemented by a hard overgrowth of quartz whereas above the level of $215.30 \mathrm{~m}$ the sandstone beds are cemented by calcite but only partially in the spotty fashion that gives the rocks a mottley appearance (Fig. 3 a). Concretionary pyrite occurs frequently and in all rock types (Fig. 3 b). The topmost greywacke beds exhibit several quartz grains with not very closely spaced shock-like lamellae as in the quartz of the tuffaceous breccia described by Laurén and others (1978, Fig. 11). The few pieces of chalcedony-like quartz observed in the greywackes and some of the sandstones may be from the quartzose dyke-fillings found earlier in erratic blocks (Laurén et al. 1978 , p. 20). Heavy minerals, especially zircon, are common in all of the sandstones and in some of the finer rocks.

The Söderfjärden sedimentary rocks exhibit well developed and preserved primary sedimentary structures undestroyed by metamorphism. The latest drilling did not reveal any essentially new structures in addition to those found by Laurén and others (1978), but it does give a more complete and detailed view along the succession of strata. A few pictures of the structures are included in this paper (Figs. 3-4), because previous discussion of the structures has been limited and unillustrated (Lehtovaara 1980, 1982). Several references to them are also made in Table 1.

As found earlier, it is evident that, at this drilling site, the sedimentary rock sequence is divisible into two main parts (Lehtovaara 1982), the dividing line lying at $215.30 \mathrm{~m}$ (see 

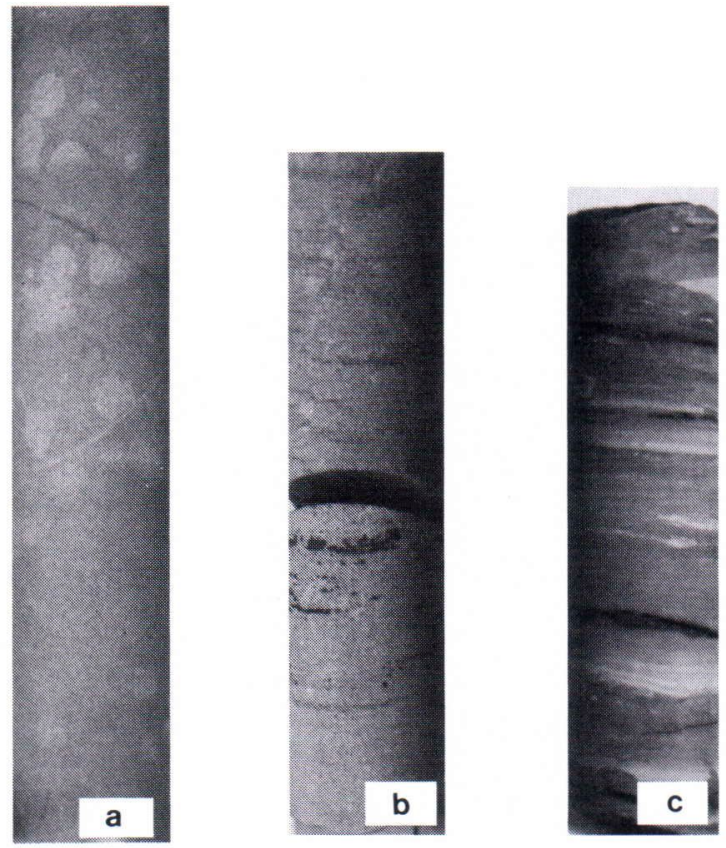

Fig. 3 a. Sandstone, greyish and fine-grained. The white spots are caused by the sporadic cementation by calcite. The depth of the sample approximately

$172.5 \mathrm{~m}$ and the diameter of the core $30 \mathrm{~mm}$.

Fig. $3 \mathrm{~b}$. Sandstone with a few laminations and dark pyrite concretions conformably with bedding. The depth approximately $185 \mathrm{~m}$ and the diameter of the core $30 \mathrm{~mm}$.

Fig. 3 c. Graded bedding in varved shale. The silty bottoms show very slightly erosional contates against the under-lying clayey tops of previous varves. The depth of the sample approximately 311 $\mathrm{m}$ and the diameter of the core $30 \mathrm{~mm}$.

Table 1). The principal syndepositional feature of the dominant shales of the lower part is the graded silt-clay varve structure (Fig. $3 \mathrm{c}$ ), which has often been masked by slumping (Fig. 4 a). In the upper half of more mixed sedimentary rocks many of the sandy layers are microfaulted (Fig. 4 b). Their rather massive bedding is seen in Fig. $3 \mathrm{a}$ and with laminations in Fig. 3 b. Even the greywacke layers and the occurrence of conglomeratic pebbles in any other rock type (Table 1) tend to enhance the characteristic instability of the
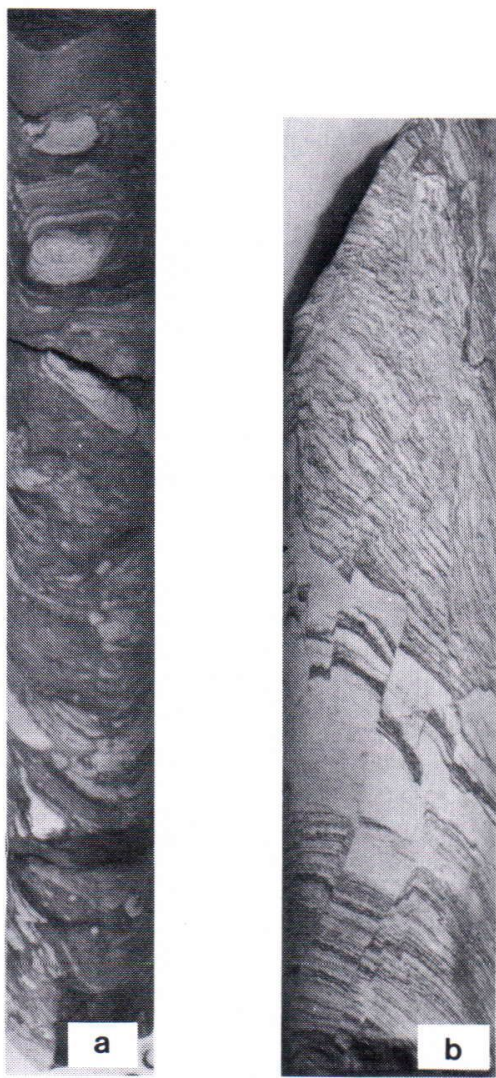

Fig. 4 a. Slumping in the varved shales. The graded varves are destroyed. The depth approximately $297.5 \mathrm{~m}$ and the diameter of the core $30 \mathrm{~mm}$.

Fig. 4 b. Sandstone with frequent laminations of clayey material, enhanced by rusting. The depth approximately $89.5 \mathrm{~m}$ and the diameter of the core $40 \mathrm{~mm}$.

Söderfjärden sedimentary beds during their initial deposition. A rapid filling of the basin is indicated, especially since all the bedding planes are now in variously inclined positions.

Some new chemical analyses have been made on the Söderfjärden sedimentary rocks. They are presented together with a few earlier ones in Table 2. When arranged in the order of the increasing $\mathrm{SiO}_{2}$ content, the Söderfjärden sedimentary rocks have a wide and obviously gradual spread in their chemical 
Table 2. Söderfjärden sedimentary rock analyses.

\begin{tabular}{lrrrrrrc}
\hline & \multicolumn{1}{c}{} & \multicolumn{1}{c}{2.} & \multicolumn{1}{c}{3.} & \multicolumn{1}{c}{4.} & \multicolumn{1}{c}{5.} & 6. & 7. \\
\hline $\mathrm{SiO}_{2}$ & 61.61 & 62.95 & 66.96 & 80.34 & 91.31 & 98.3 & 67.1 \\
$\mathrm{TiO}_{2}$ & 0.96 & n.d. & 0.11 & 0.45 & 0.53 & n.d. & n.d. \\
$\mathrm{Al}_{2} \mathrm{O}_{3}$ & 16.36 & 18.21 & 14.29 & 6.14 & 4.17 & 0.50 & 2.3 \\
$\mathrm{Fe}_{2} \mathrm{O}_{3}$ & 2.69 & 2.72 & 1.40 & 2.12 & 0.22 & $0.15^{\text {a }}$ & 1.0 a \\
$\mathrm{FeO}$ & 5.09 & 3.4 & 4.10 & 2.05 & 0.57 & n.d. & n.d. \\
$\mathrm{MnO}$ & n.d. & 0.03 & n.d. & n.d. & n.d. & n.d. & n.d. \\
$\mathrm{MgO}$ & 1.26 & 2.10 & 1.33 & 0.91 & 0.18 & n.d. & 3.8 \\
$\mathrm{CaO}$ & 0.38 & 0.45 & 0.74 & 1.71 & 0.10 & 0.46 & n.d. \\
$\mathrm{Na}$ & 0.17 & 0.21 & 0.18 & 0.10 & 0.07 & 0.01 & 0.04 \\
$\mathrm{~K}_{2} \mathrm{O}$ & 3.43 & 4.25 & 3.31 & 2.17 & 1.11 & 0.11 & 0.44 \\
$\mathrm{P}_{2} \mathrm{O}_{5}$ & 0.05 & 0.08 & 0.15 & 0.26 & 0.03 & n.d. & 8.9 \\
$\mathrm{H}_{2} \mathrm{O}+$ b & 6.99 & 4.98 & 5.49 & 3.47 & 1.58 & n.d. & 3.8 \\
$\mathrm{~S}$ & 0.27 & 0.40 & 0.40 & 0.07 & 0.11 & n.d. & n.d. \\
\hline total & 99.31 & 99.80 & 98.99 & 99.89 & 99.98 & 99.5 & 100.1 \\
\hline
\end{tabular}

1. Shale (claystone). Drill hole $\mathrm{SF}-1,154.30 \mathrm{~m}$.

2. Fine siltstone. Drill hole $\mathrm{D}_{3}, 73.35 \mathrm{~m}$ (Laurén et al., 1978).

3. Silty varve in shale. Drill hole $\mathrm{SF}-1,117.15 \mathrm{~m}$.

4. Glauconitic silty sandstone. Drill hole $\mathrm{SF}-1,137.90$.

5. Laminated sandstone. Drill hole $\mathrm{SF}-1,89.18 \mathrm{~m}$.

6. Whitish sandstone. Boulder 59-e, Malax (Laurén et al., 1978).

7. Calcareous phosphorite conglomerate. Drill hole $\mathrm{D}_{3}^{-}$(Laurén et al., 1978).

a. total iron

b. ignition loss at $1000^{\circ} \mathrm{C}$

All analyses are made at Partek Development Centre, Parainen, using standard wet chemical methods.

compositions. The purest sandstones are very pure orthoquartzites. Silty and glauconite impurities gradually reduce the preponderance of quartz into the fields of protoquartzites and even greywackes (classification of Selley 1976). In calcareous sandstones the $\mathrm{CaCO}_{3}$ cement may rise to almost half the volume of the rock; normally it is much less. In the clayey rocks, on the other hand, $\mathrm{SiO}_{2}$ does not seem to drop below $60 \%$, although the content of $\mathrm{Al}_{2} \mathrm{O}_{3}$ may be rather high. Thus, microscopical observations on the relatively coarse grain size of the clayey material seem to be corroborated by the chemical analyses.

Table 3 shows the phosphorus and uranium contents of samples along the entire length of the drill core. The values are very constant and at low percentages. The $\mathrm{P}_{2} \mathrm{O}_{5}$ content of the conglomeratic rocks is lower than those reported earlier (Laurén et al. 1978, p. 25) and in the top values of the Bothnian Sea (Thorslund and Axberg 1979). The uranium value increases only slightly in the conglomerate; nowhere are the values more than a few ppm. Table 4 presents the very low contents of some heavy metals in a pyrite concretion in accordance with earlier analyses by Lonka and Papunen (1968) and by Thorslund and Axberg (1979).

\section{Discussion}

This first intersection of the whole sedimentary pile at Söderfjärden is revealing in several aspects. The vertical thickness of the variously dipping sedimentary rocks in the Söderfjärden basin has now been found to exceed $200 \mathrm{~m}$ (p. 38). This is exceptionally high, as the drilled Lower Cambrian beds reach only $30-40 \mathrm{~m}$ in the Bothnian Sea 
Table 3. Phosphorus and uranium contents of Söderfjärden sedimentary rocks.

\begin{tabular}{lccc}
\hline rock type & depth & $\begin{array}{c}\mathrm{P}_{2} \mathrm{O}_{5} \\
(\%)\end{array}$ & $\begin{array}{c}\mathrm{U} \\
(\mathrm{ppm})\end{array}$ \\
\hline graywacke & 78.45 & 0.06 & 2.86 \\
varved shale & 83.20 & 0.06 & 4.26 \\
reddish sandstone & 89.18 & 0.03 & 1.49 \\
graywacke & 92.70 & 0.09 & 5.40 \\
silty varve & 117.15 & 0.15 & 2.80 \\
glauc. silty sdst & 137.90 & 0.26 & 2.11 \\
conglomeratic sh. & 142.37 & 0.48 & 2.92 \\
shale & 154.30 & 0.05 & 3.02 \\
shale & 186.70 & 0.10 & 4.03 \\
silty shale & 201.05 & 0.06 & 3.74 \\
shale & 216.50 & 0.08 & 3.26 \\
shale & 237.60 & 0.05 & 2.79 \\
shale & 255.20 & 0.06 & 2.64 \\
conglomerate & 262.00 & 2.9 & 6.33 \\
silty shale & 276.00 & 0.14 & 2.98 \\
shale & 296.20 & 0.04 & 2.70 \\
graywacke & 317.55 & 0.02 & 3.27 \\
\hline
\end{tabular}

Phosphorus analyzed at Partek Devel. Centre, Parainen, spectrophotometrically, and uranium at VTT, Espoo, using neutron activation analysis.

(Thorslund and Axberg 1979). According to Winterhalter (1972), the maximum thickness is probably more, and, according to Lehtovaara (1982), the remnants on the mainland are much thinner still. Owing to the intersection it is understandable that no other, i.e. Jotnian, sedimentary rocks have been met with on the basin floor. Geologically speaking, the deep (more than $300 \mathrm{~m}$ ) local basin was formed rapidly. This is manifested by the chaotic manner in which it filled, as has been deduced from the sedimentation and deformation structures (p. 40 and Lehtovaara 1982 , p. 19) and the paleontological data (Tynni, pers. comm. and this issue). Any earlier sedimentary cover was blown out during the cratering process or then it never existed.

Sedimentation in the Söderfjärden basin is now shown to have proceeded swiftly (viz. structures) and under marine conditions (tourmaline, glauconite) ever since it first
Table 4. Trace metal contents of a pyrite concretion at $138.22 \mathrm{~m}$ in siltstone.

\begin{tabular}{lrlrll}
\hline & ppm & \multicolumn{3}{c}{ ppm } & wt\% \\
\hline $\mathrm{Cu}$ & 49 & $\mathrm{Ni}$ & 53 & $\mathrm{Fe}$ & $0.91^{*}$ \\
$\mathrm{Zn}$ & 21 & $\mathrm{Co}$ & 20 & $\mathrm{~S}$ & 29.5 \\
$\mathrm{~Pb}$ & 44 & $\mathrm{Cr}$ & 2 & & \\
\hline
\end{tabular}

* soluble

Analysed at Partek Devel. Centre, Parainen, using AAS method.

began to fill with greywacke-like unsorted material. The process was very complex in detail and, as deduced from rock-type observations at only one drilling point, the feeding currents shifted rapidly, being loaded with clastic material of frequently changing grainsize composition carried down from different levels of the sedimentation environment. The geological history of the sedimentation is discussed further in Lehtovaara (1982).

In this context it is important to note the Lower Cambrian age of the sedimentary filling and, consequently, of the sedimentation basin, the crater, as well. The roundish shape of the Söderfjärden plan section, approximated in Fig. 1, suggests to the author that such a rare feature in the Precambrian bedrock cannot have been formed by normal tectonic downfaulting, even though several strikes of tectonic lineaments are discernible in the local bedrock (Talvitie et al. 1975). Rather, several postorogenic alkaline intrusions developed almost simultaneously with the birth of the Söderfjärden crater in the Fennoscandian Shield. The Alnö alkaline intrusion on the western side of the Bothnian Sea was formed some $589 \mathrm{Ma}$ ago (recalculated, Welin 1979). The Fen alkaline intrusion in southern Norway has also been dated at $585 \mathrm{Ma}$ (Oftedahl 1980). Iivaara, c. $500 \mathrm{~km}$ $\mathrm{NE}$ of Söderfjärden, is $430 \mathrm{Ma}$ old (Doig 1970). 
The preliminary drilling into the Söderfjärden sedimentary rocks (Laurén et al. 1978) and the latest drilling incline the author to conclude that, on the basis of age similarities, Söderfjärden may be the result of an abortive alkaline (?) intrusion associated with areal alkaline magmatism. No, or a very minute amount of, lava was erupted, the activity having been reduced to the violent, explosive escape of gases through the Söderfjärden vent. The explosion cleared the crater.
A caldera-like subsidence may have further contributed to the formation of the Lower Cambrian Söderfjärden basin. A water-muffled meteorite-impact might be capable of creating Söderfjärden, but direct proof of such an origin is even more difficult to produce.

Acknowledgements. I wish to thank prof. H. Papunen and Dr. Risto Tynni for fruitful discussions.

\section{References}

Doig, R., 1970. An alkaline province linking Europe and North America. Can. J. Earth Sci. 7, $22-29$.

Laurén, L., Lehtovaara, J., Boström, R. and Tynni, $R$., 1978. On the geology and Cambrian sediments of the circular depression at Söderfjärden, western Finland. Geol. Surv. Finland, Bull. 297, $81 \mathrm{p}$.

Lehtovaara, J., 1980. Selostus kairaustuloksista Vaasan Söderfjärdenillä kesällä 1979. Unpublished drillings report.

Lehtovaara, J., 1982. Palaeozoic sedimentary rocks in Finland. Ann. Acad. Sci. Fennicae A III, 133, $35 \mathrm{p}$.

Lonka, A. and Papunen, H., 1968. Pyrite-bearing sandstone blocks, western Finland. Bull. Geol. Soc. Finland 40, 99-106.

Oftedahl, Chr., 1980. Geology of Norway. Norges Geol. Unders. 356, 3-114.

Pettijohn, F. J., 1975. Sedimentary rocks. Harper \& Row, $628 \mathrm{p}$.
Selley, R. C., 1976. An Introduction to Sedimentology. Academic Press, 408 p.

Talvitie, J., Pernu, T. and Raitala, J., 1975. The circular Vaasa structure in the Baltic Shield, western Finland. Dept. Geophys., Univ. Oulu Contr. 59, 15 p.

Thorslund, P. and Axberg, S., 1979. Geology of the southern Bothnian Sea. Bull. Geol. Inst. Univ. Uppsala, New Series 8, 62 p.

Tynni, R., 1982. New results of studies on the fossils in the Lower Cambrian sediment deposit of the Söderfjärden basin. Bull. Geol. Soc. Finland $54,1-2,57-68$.

Welin, E., 1979. Tabulation of recalculated radiometric ages published 1960-1979 for rocks and minerals in Sweden. Geol. Fören. Stockh. Förh. 101: 4, 309-320.

Winterhalter, B., 1972. On the geology of the Bothnian Sea, an epeiric sea that has undergone Pleistocene glaciation. Geol. Surv. Finland, Bull. 258, 66 p.

Manuscript received, March 29, 1982 